\title{
The Impact of The Pandemic on Development Creative Industries and The Welfare Freelance Workers in The City of Sidoarjo
}

\author{
Zulifah Chikmawati ${ }^{1}$, Ayu Lucy Larassaty ${ }^{2}$ Riyan Sisiawan Putra ${ }^{3}$ \\ ${ }^{l}$ Faculty of Economics, University of Nahdlatul Ulama Sidoarjo, Monginsidi In Kav Parliament, Sidoklumpuk, \\ 61218, Sidoarjo \\ ${ }^{2}$ Faculty of Economics, University of Nahdlatul Sidoarjo Ulama, Monginsidi In Kav DPR, Sidokl stack, 61218, Sidoarjo \\ ${ }^{3}$ Faculty of Economics and Business, Nahdlatul Ulama University Surabaya, Jln Raya Jemursari Wonocolo, 60237, \\ Surabaya \\ *Corresponding author. Email: hikmawatizulifah@gmail.com
}

\begin{abstract}
The emergence of Covid-19 is very influential in all sectors of the world, one of which is the economic aspects and the welfare of workers began to weaken and freelance workers were vacated so that it affected the development of the creative industry that occurred in Sidoarjo City went bankrupt. Therefore the purpose of this study (1) Determine what methods can improve the development of creative industries in the midst of a pandemic in order to increase the income for the City of Sidoarjo, (2). Knowing the forms of welfare implementation of casual daily laborers in Sidoarjo City, (3). Knowing the difference in the welfare improvement of freelance workers before the pandemic and after the pandemic in Sidoarjo City. This study uses a Mix Method with a sample of 10 creative industries and 146 casual workers in the city of Sidoarjo. The first finding, this study explains that there are four methods it can be used, namely welfare, (2) competition, (3) growth and (4) innovation. Second, the welfare of casual daily workers $60 \%$ has not been implemented properly as seen from the fate of casual daily workers who do not have the strength and the means to fight for their fate when a pandemic is affected so that companies in the city of Sidoarjo that are engaged in the creative industry sector are allowed to continue to operate using protocols and SOPs that must be obeyed to reduce the unemployment rate in the city of Sidoarjo because the company is unable to provide wages when workers leave the Work Form Home. Third, a significant difference in which to improve the welfare of freelancers is realized by increasing the climate of high cooperation to be able to increase wages, working conditions, employment relationships, work safety and social security.
\end{abstract}

Keywords: Creative Industries, the welfare of freelance workers And the Pandemic

\section{INTRODUCTION}

Creative industries can be interpreted as a very important component to building an economy to be more advanced so that the creative industries are mapped to be able to synergize the use of creativity, skills, and utilization of creative power and innovation power, Larassaty [1]. Creative industries is a new analytic definition of industry in an economy where creativity is input and content or intellectual property, Potts \& Cunningham [2] So it can be concluded that the creative industry can create a positive business climate, can strengthen the image and identity of the Indonesian nation, can support the use of renewable resources and is central to the creation of innovation and the formation of creativity. This makes economic actors pay attention to the development of the creative economy as well.

The development of the creative economy emerged in the United Kingdom which was later adopted by several countries, one of which was Indonesia. As a creative industry business actor must have a goal to create prosperity and employment by producing and exploiting the creative power and creativity of individuals, both individually and working groups, Rochani [3]. Creating 


\section{Procedia Business and Financial Technology}

Proceedings of the 2nd International Conference on Business and M anagement of T echnology (ICO N BM T 2020) - Part 2

prosperity to human resources (workers) in this creative industry can create added value determined by the intellectual ability of human capital (human capital).

This intellectual ability can affect the improvement of human resources, especially in casual daily employees, where the company now has to find workers who have social capital, intellectual capital, mental capital, spiritual capital, emotional capital, motivational capital, the existence of these six models will foster creative ideas and innovative. This capital must be balanced with the welfare that will be obtained by every worker because the welfare obtained both salary and other support can affect the productivity of acompany.

\section{BACKGROUND}

In 2020 Indonesia suffered a very deep wound because of Covid-19 which affected all aspects of the world, one of which was the economy and employee welfare began to weaken. The weakening of the economy and the welfare of these employees also affected the development of the creative industry, where Sidoarjo was one of the SME and UMKM developers who received the Natamukti award obtained from the International Indonesia Courcil For Smaal Business (ICSB) in 2018, Kominfo [4].

This makes the Sidoarjo government must keep the spirit of assisting growth the economy and welfare of the people in Sidoarjo can continue to survive by prioritizing creative and innovative human resources by using technological developments to penetrate the world market, Fitriana [5]. The development of increasingly advanced technology is balanced by human resources that can adapt to penetrate the resource-based economic paradigm that can achieve knowledge and creativity-based economy so that, it can affect the growth and development of creative industries in modern economic development which is very significant to innovative new technology with technology and communication that can improve business today, Larassaty [1].

Today's creative industry business world must be able to face challenges because it requires expertise and reliability of creative human resources Nasir \& Muhammad [6]. Based on the survey results of the Central Statistics Agency (BPS) Sidoarjo Regency explained that the number of workers absorbed by the category of medium and large industries 162,650 thousand workers but with the existence of the Covid-19 case has an impact on labor welfare which affects the number of casual workers who are vacated due to economic movements which weakened so that it affected the development of the creative industries that occurred in the city of Sidoarjo out of business, which affected 329 workers. The results of $156 / 180$ research conducted by Mardiyah \& Nurwati [7] in his research explained that the number of unemployed people who were temporarily stopped and layoffs caused by the impact of Covid-19 which could result in poverty and many MSMEs are out of business due to considerable losses. Research conducted by Nasution [8] shows that the development of creative industry businesses to survive and be able to survive in the pandemic Covid-19 is to create intellectual property rights (IPR). Based on the results of the research above the problems that occur in the creative industry environment and the many unemployment rates due to lack of welfare for casual workers caused by the Covid- 19 case this has become one of the polemics that must be considered by academics (1). to be able to provide solutions to the government and the community related to what methods can increase the development of creative industries in the current pandemic to increase the revenue of Sidoarjo City, (2). Knowing the forms of welfare implementation of casual daily workers in Sidoarjo City, (3). Knowing the difference in the welfare improvement of freelance workers before the pandemic and after the pandemic in Sidoarjo City.

\section{METODOLOGY}

This research uses a mixed-method method where this method is a mixture of qualitative and quantitative research types, Sugiyono [9]. The samples in this study were 10 creative industries and 146 freelancers in the city of Sidoarjo. 10 creative industries are used to measure the qualitative approach and 146 workers are used to measure the quantitative approach. The subjects of this study were creative industry practitioners in the city of Sidoarjo and casual workers in the city of Sidoarjo.

The data analysis technique used in this study is the initial step taken is to collect data and analyze quantitative data and collect qualitative data using interview drafts. The results of the study are used to explain more clearly the phenomena explained from the results of quantitative research using a paired sample t- test. All data obtained were analyzed with explanatory mixed-method analysis, Sugiyono [9]. Begins with quantitative data analysis using descriptive quantitative techniques, followed by an explanation and elaboration of the quantitative findings using qualitative data sets that have been obtained with qualitative techniques. Data types, data categories, data collection techniques, instruments used, and data sources are presented in Table 1 below: 


\section{Procedia Business and Financial Technology}

Proceedings of the 2nd International Conference on Business and M anagement of T echnology (ICO N BM T 2020) - Part 2

Table 1 Types and Categories of Data / Information Collected, Data Collection Techniques, Instruments, and Data Sources

\begin{tabular}{clccc}
\hline No & \multicolumn{1}{c}{ Data Types and Categories } & $\begin{array}{l}\text { Data Collection } \\
\text { Techniques and } \\
\text { Methods }\end{array}$ & Instrument & Data source \\
\hline 1 & $\begin{array}{l}\text { The method used to develop creative } \\
\text { industries in the midst of a pandemic }\end{array}$ & Interview & Interview guide & $\begin{array}{l}\text { Creative Industry } \\
\text { Business Actors }\end{array}$ \\
\hline 2 & $\begin{array}{l}\text { Implementation of the welfare of casual } \\
\text { daily laborers in Sidoario City }\end{array}$ & Interview & Interview guide & $\begin{array}{l}\text { Creative Industry } \\
\text { Business Actors } \\
\text { and Sidoario } \\
\text { Regency Manpower } \\
\text { Office }\end{array}$ \\
\hline 3 & $\begin{array}{l}\text { Differences in the improvement of the } \\
\text { welfare of casual workers before the } \\
\text { pandemic and after the pandemic in Sidoario } \\
\text { City }\end{array}$ & Questionnaire & Questionnaire & $\begin{array}{l}\text { Welfare Freelance } \\
\text { Workers }\end{array}$ \\
\hline
\end{tabular}

\section{RESULTS AND DISCUSSION}

The survey results in this study are shown based on the identification of respondents of casual daily laborers used by researchers as samples in this study which are shown as follows:

a. Survey Results Based On Respondents Gender The survey results in Figure 1 below can be explained that the respondents participated filling the questionnaire based on the gender of men as much as $65 \%$ while women as much as $81 \%$.

Figure 1 Survey results based on respondents gender

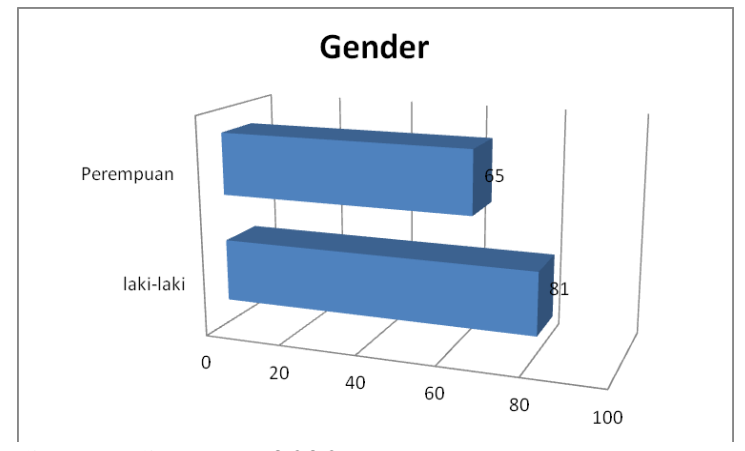

Source: Statistics 2020

b. Survey Results Of Respondents Based On Age The survey results in Figure 2 below can be explained that the respondents participated in filling the questionnaire based on the age of 20-30 years as much as 9\%, aged 3140 years as much as $34 \%$ while the rest were aged $41-50$ years as much as $57 \%$.
Figure 2 Survey Results Of Respondents Based On Age

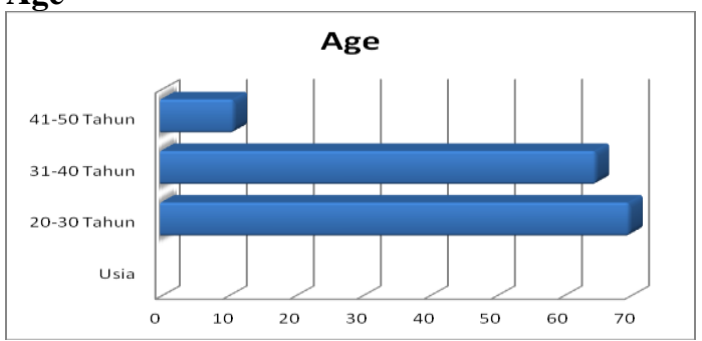

Source: Statistics 2020

c. Creative Industry Development Methods Based on the results of ten MSME interviews in the city of Sidoarjo, the opinion is that MSME and creative industry SMEs are starting to decline during the Covid19 pandemic. This makes the business actors not only remain silent but the creative industry entrepreneurs start to use accurate strategies to increase revenue. Many problems that arise during the Covid-19 epidemic for businesses, one of which is marketing, the acquisition of difficult raw materials, the welfare of employees, especially casual daily laborers, all companies began to tighten their belts to survive. Not all creative industry sub-sector work can be done from home even though the creative industry is often identified with technological expertise, production activities in many sub-sectors are still affected and impossible to do from home. those who worked in the film, video, and audiovisual subsectors (17.35\%) were the ones who experienced the most work cancellations due to the covid-19 pandemic.

Job cancellations or projects in this profession occur because these jobs are difficult to do from inside the house. picture taking in film/video production, for example, cannot be done from inside the house because it 


\section{Procedia Business and Financial Technology}

Proceedings of the 2nd International Conference on Business and M anagement of T echnology (ICO N BM T 2020) - Part 2

is site-specific, besides that in the production process, people/workers must be clustered in the location of the image that is therefore vulnerable to Covid-19 transmission. Similar barriers also occurred in the 3 mostaffected subsectors, namely: a. performing arts $(10.85 \%)$, b. vocal arts and music $(9.4 \%)$, and c. photography $(9.4 \%)$. Jobs in the three sub-sectors indeed require workers to work outside the home. moreover, jobs in the performing arts and vocal and music subsectors generally require a large crowd. some artists/musicians may be able to do their work from home and do many alternatives such as online concerts using video streaming channels, but we also need to be observant that in the subsector chain some work as stage or field crews - the job is not possible remotely. The 5th affected subsector is research $(7.2 \%)$ and visual communication design (7.2\%). Job cancellation in the research sub-sector is related to work restrictions outside the home. in this context, research activities such as fieldwork and lab observation, to some degree, cannot be replaced by relying only on existing facilities in the home.

The global crisis, which does not know when it ends, invites all creative industry businesses in the city of Sidoarjo to have the right strategy to develop their business, one of which is by monitoring finance. to increase the activities of the creative industries, the creative industries must (1). able to manage company management that started using a traditional management system must now be able to use a modern management system through market share determination using segmentation strategies, targeting, and product positioning. This is used to be able to build products so that they can enter existing markets and even create their markets. (2) determining aspects of the marketing mix. (3) using promotional media, monitoring, and evaluating business development. (4) the use of good and quality employees will make an asset to the company. (5) Strive for changes in technology transfer by adopting newly developing technologies in the industrial world.

The existence of Covid-19 can be concluded that the implementation of industry 4.0 as an effort to arouse the enthusiasm of creative industry players in the city of Sidoarjo to apply four methods in developing their business, namely (1) welfare given to employees by encouraging new work patterns, (2) competition in the business world, (3) increased revenue growth and (4) innovation in doing business development by adopting the technology. This research is in line with research conducted by Rochani [2] explained that the development of creative industries is very congress by relying on employees, creativity, and intelligence in seeing business opportunities to become a productive economic sector in the current technological era so that, the development of creative industries has a very high opportunity to be developed as the basis of the people's economy.

\section{Form of Implementation of Welfare Daily Freelance Workers in Sidoarjo City}

Based on the results of interviews with MSME casual daily laborers in the city of Sidoarjo during the Covid-19 pandemic, it can be explained that some of the problems experienced by low-income, low-income daily workers are at risk of wage cuts and job loss. This is worsened by the phenomenon of large-scale social restrictions (PSBB) so that many workers are homeless without being paid their wages and even experience layoffs (Termination of labor). In addition, there are still many MSMEs in Sidoarjo who have not been able to apply a clean lifestyle and adequate occupational health standards by using K3 protection such as masks, hand sanitizers, and PPE (personal protective equipment). Even work at home policies cannot be carried out as casual daily laborers, which is a problem for casual dailyworkers.

This problem does not escape the interference of the government in which, the government and business actors must be able to pay attention to the welfare of casual daily workers. Business actors have not been able to provide welfare by providing wages to casual daily workers when working from home, because businesses must also pay attention to operational costs incurred. The results of interviews with the Sidoarjo regency office can be revealed that in May 2020 every freelance worker gets direct cash assistance (BLT) of Rp. 600,000, - per Family Card (KK) but the implementation of $60 \%$ of the number of Family Cards (KK) has not been obtained equally.

This is in line with the results of research conducted by Ekarahendy, Izzati, Farhanah, Rio Apinino, \& Raharjo

[10] explain from the results of his research Increasing the number of workers affected by COVID-19 through the Sidoarjo Regency Manpower Office data collection channel still lacks clear follow-up, especially for those who do not have their rights. Violations of OSH in the workplace also have not been seen to be improved in conditions that are harmful to health. Another policy that needs to be responded critically is the Work Card, which when this position paper was completed, was officially launched (on 11 April 2020). By promising incentives of Rp2,400,000 for 4 months (or Rp.600,000 / month) along with training incentives of Rp1,000,000 for each worker.

\section{Differences in Increased Welfare of Workers Off Before the Pandemic and After the Pandemic in Sidoarjo City}

Based on the results of the management of the paired sample $t$ test different test analysis can be shown in table 2 below:

(1)




\section{Procedia Business and Financial Technology}

Proceedings of the 2nd International Conference on Business and M anagement of T echnology (ICO N BM T 2020) - Part 2

Tabel 2 Paired Sample t Test

\begin{tabular}{llll}
\hline $\mathbf{t}$ & df & $\begin{array}{l}\text { Sig. (2- } \\
\text { tiled) }\end{array}$ \\
\hline Pair 1 Before-After & 4.513 & 145 & .000 \\
\hline
\end{tabular}

\section{Source: Statistics 2020}

The results of the analysis of table 2 above can be explained that this is indicated from the results of the data above that the significance value of $0.000>0.05$ indicates that there are differences in the welfare improvement of Freelance Workers Before Pandemic and After Pandemic in Sidoarjo City. to improve the welfare of freelancers is realized by increasing the high climate of cooperation to be able to increase wages, working conditions, work relationships, work safety and social security that have not been fulfilled so that, increasing unemployment and increasing poverty.

The results of this study are in line with research conducted by Anwar \& Setiawan [11] explained that the results of this study showed that there were differences in income and the level of welfare of daily laborers who remained more prosperous compared to permanent workers. The factors that most influence the level of welfare of daily laborers are the daily worker's income is still greater than the income of permanent workers.

\section{CONCLUSION}

The results of the analysis and discussion above can be concluded that :

a. There are four methods that can be used, namely (1) welfare, (2) competition, (3) growth and (4) innovation.

b. The welfare of casual daily workers $60 \%$ has not been implemented properly as seen from the fate of casual daily workers who do not have the strength and the means to fight for their fate when a pandemic is affected so that companies in the city of Sidoarjo that operate a creative industry sector are allowed to continue to operate using protocols and SOPs that must be obeyed to reduce the unemployment rate in the city of Sidoarjo because companies cannot afford to provide wages when workers leave the Work Form Home.

c. Here is a significant difference in where to improve the welfare of casual workers is realized by increasing the climate of high cooperation to beable to increase wages, working conditions, employment relationships, work safety, and social security.

\section{ACKNOWLEDGMENT}

This research was supported by Nahdlatul Ulama University Sidoarjo, Nahdlatul Ulama University Surabaya, Faculty Economics of the Nahdlatul Ulama
University, Sidoarjo SMEs and the Sidoarjo Regency Manpower Office

\section{REFERENCES}

[1] Larassaty, A. L. (2016). Kontribusi Sumber Daya Manusia Di Bidang Industri Kreatif Untuk Meningkatkan Kinerja Pariwisata ( Studi Kasus Pada Dinas Kebudayaan Dan Pariwisata Kebupaten Pasuruan ). Prosiding Seminar Nasional Ekonomi Dan Bisnis \& Call For Paper FEB UMSIDA 2016, 95-113.

[2] Potts, J., \& Cunningham, S. (2010). Four Models of the creative industries. L'economie De La Culture, 120, 163-180.

[3] Rochani, A. (2017). Strategi Pengembangan Industri Kreatif Dalam Mewujudkan Kota Cerdas. Inovasi Dalam Pengembangan, 81-93.

[4] Kominfo. (2018). Berhasil Kembangkan UMKM Pemkab Sidoarjo Raih Penghargaan Natamukti dari Menteri Koperasi dan UKM. Retrieved November 16, 2018, from Kabupaten Sidoarjo website: http://portal.sidoarjokab.go.id/berhasil-

kembangkan-umkm-pemkab-sidoarjo-raihpenghargaan-natamukti-dari-menteri-koperasi-danukm

[5] Fitriana, A. N. (2014). Pengembangan Industri Kreatif Di Kota Batu (Studi Tentang Industri Kreatif Sektor Kerajinan Di Kota Batu). Jurnal Administrasi Publik Mahasiswa Universitas Brawijaya, 2(2), 281-286.

[6] Nasir, \& Muhammad, S. (2017). Dampak Industri Kreatif Dan Strategi Terhadap Peningkatan Kesejahteraan Masyarakat Di Kabupaten Aceh Besar (Studi Pada Subsektor Industri Kerajinan Di Kabupaten Aceh Besar. Eminar Nasional II USM, 1, 432-436.

[7] Mardiyah, R. A., \& Nurwati, R. N. (2020). Dampak pandemi covid-19 terhadap peningkatan angka pengangguran di indonesia. Retrieved from Academia.edu website: https://www.academia.edu/42890039/dampak_p andemi_covid_19_terhadap_peningkatan_angka_p engangguran_di_indonesia?auto=download.

[8] Nasution, L. (2020). Efektifitas HKI Sebagai Pelindung Industri Kreatif dan UMKM Di Tengah Pandemi Covid-19. Adalah Buletin Hukum \& Keadilan, 4(1), 238250. https://doi.org/10.15408/adalah.v4i1.16466

[9] Sugiyono. (2017). Metode Penelitian Kombinasi (Mixed Methods). In Alfabeta.

[10] Ekarahendy, E., Izzati, F. F., Farhanah, Rio Apinino, \& Raharjo, I. (2020). Mengubur Pundi Di Tengah Pandemi (Kerentanan Pekerja Lepas di tengah Krisis Covid-19). In SINDIKASI. Jakarta: 


\section{Procedia Business and Financial Technology}

Proceedings of the 2 nd International Conference on Business and M anagement of T echnology (ICON BM T 2020) - Part 2

Serikat Pekerja Media dan Industri Kreatif untuk Demokrasi (SINDIKASI).

[11] Anwar, K., \& Setiawan, H. (2018). Analisis perbandingan pendapatan buruh harian tetap dengan buruh harian lepas dan pengaruhnya terhadap kesejahteraan keluarga buruh perkebunan kelapa sawit di kota subulussalam. Ekonomi Pertanian Unimal, 01(1), 73-81. https://doi.org/https://doi.org/10.29103/jepu.v1i2.86 4 